\title{
El concepto de la tolerancia religiosa en Chile en la primera mitad del siglo XIX: a propósito de dos documentos diplomáticos británicos de 1854
}

\section{The concept of religious tolerance in Chile during the first half of the} 19th century: two british diplomatic documents from 1854

\author{
José Antonio González Pizarro * (i) https://orcid.org/0000-0002-4030-0353 \\ *Universidad Católica del Norte, Antofagasta, Chile. Profesor. Doctor en Historia, U. de Navarra. \\ @jagonzal@ucn.cl
}

\section{(cc) BY}

Resumen:

Se examina el concepto de la tolerancia religiosa durante el denominado régimen portaliano, poniendo énfasis cómo fue entendido por la Iglesia, por los liberales de la época y cómo fue resuelto por los gobiernos nacionales, desde O'Higgins hasta Montt, en el marco del régimen de patronato. Se resalta el contexto de las relaciones diplomáticas de Chile con los países europeos y de los avances en la materia en el continente latinoamericano, para comprender las asociaciones ideológicas con otras nociones, que hicieron de la cuestión de la tolerancia religiosa un asunto totalizador, para la Iglesia, los liberales, la diplomacia europea $y$, en cierta forma, acogida por los gobiernos en sus tratados con las potencias europeas.

Palabras Clave: Patronato; Iglesia; Protestantes; Tolerancia; Cementerios.

\begin{abstract}
:
The concept of religious tolerance during the so-called Portales regime is examined, putting emphasis on how it was understood by the Church, the liberals of that time, and how it was solved by national governments, from O'Higgins to Montt, within the framework of patronage regime. The context of Chilean diplomatic relations with European countries and their advances in the Latin American context are analyzed to understand the ideological associations with other concepts that turned tolerance into a totalizing matter for the Church, liberals, European diplomacy, and, to some extent accepted by governments in their treaties with European powers.
\end{abstract}

Keywords: Patronage; Protestants; Church; Tolerance; Cemeteries. 


\section{Introducción}

Dentro de las relaciones entre la Iglesia y el Estado en Chile en el curso del siglo XIX, cabe dividir éstas en dos fases. En ambas, el telón de fondo fue la herencia del régimen del patronato, que condicionó las acciones y libertades de ambas entidades.

Una primera etapa puede enmarcarse durante la vigencia de las denominadas administraciones conservadoras, que funcionaron en lo que Bravo Lira (1992) rotula el Estado Constitucional Nacional Católico, que tuvo un matiz en el gobierno de transición de José Joaquín Pérez M., y la interpretación del artículo 5 de la Constitución de 1833, que se verificó en 1865 (Estellé Méndez, 1967). La segunda fase envuelve las directrices liberales que acompañaron a los gobiernos respectivos, desde Federico Errázuriz hasta el de José Manuel Balmaceda. En este periodo hallamos la solución de los entierros para los disidentes en 1871 y principalmente las denominadas leyes laicas bajo Domingo Santa María, 1883-1884, y las tensionadas relaciones estatales entre el Vaticano y el Estado de Chile.

Nos interesa centrarnos en uno de los contenidos de las relaciones entre la Iglesia y el Estado, el de la libertad de conciencia en su vinculación con los cementerios que quedaban anejo a los terrenos de la Iglesia y bajo el cuidado eclesiástico. Materia sensible para los no católicos, máxime cuando tales expresiones van a provenir de la colonia extranjera más influyente en el país, como fue la inglesa. En la visión anglosajona, esta cuestión envolvió un criterio respecto de la tolerancia religiosa, que debía primar entre las naciones civilizadas.

Sin embargo, los conceptos en torno a tolerancia o libertad religiosa van a estar enmarcados en contextos históricos, en los cuales sus significados debieron ser asumidos en su realidad. Esto es importante, pues la tolerancia religiosa pudo ser apreciada desde diversas ópticas, en conexión con la doctrina católica teológica y canónica; desde la perspectiva de los derechos individuales, o cierta distinción entre lo racional y justo que debía prevalecer en sociedades civilizadas- o sea, acorde con los tiempos de los países rectores europeos- o desde posiciones intransigentes o, si se quiere, más apegadas a mantener la exclusividad de la confesionalidad del Estado (Llamazares Fernández, 2002).

Habrá, entonces, que apuntar, en lo que nos interesa tratar, que el concepto de tolerancia religiosa, en la primera mitad del siglo XIX, se asumió de modo distinto, 
pues constituía un concepto polisémico, según fuesen las vertientes o fuentes que se tuvieran presentes y por la finalidad que se asignaba a la sociedad ${ }^{1}$

En tal sentido, queremos adentrarnos a una situación planteada por la diplomacia británica durante el gobierno de Manuel Montt, precisamente de cómo entiende la tolerancia religiosa, acudiendo a precedentes de la génesis de la república $y$, ahora, a la necesidad de rubricar las relaciones internacionales en un tratado que contenga algún criterio sobre la materia.

Empero, las acciones ocurridas bajo la administración Montt, en sus dos periodos, 1851-1861, deben leerse en un contexto mayor. Se debe considerar en el marco continental no solo la influencia europea, de tipo helénica, en el plano de las ideas y la cultura, sino la presencia vigilante- naves de guerra- en los países latinoamericanos para "resguardar" a sus súbditos y bienes en esta área; de igual modo, la modalidad de la discusión del tema en la disputa genérica de los bandos liberales y conservadores hispanoamericanos que asumieron, a veces, otras nomenclaturas, para dirimir la acción del estado, la fisonomía de la sociedad y los derechos que tendrían sus ciudadanos.

Para la finalidad de este trabajo, abordaremos la temática de la tolerancia religiosa y la posición doctrinal católica y el "modo de encarar" en la práctica la observancia del régimen de patronato por parte de los gobiernos chilenos antes de Manuel Montt, desde las posturas ideológicas indicadas, para seguidamente aproximarnos a visualizar los tratados internacionales de Chile con los EE.UU., Francia y Gran Bretaña y examinar el marco socio-político que debe enfrentar Montt, en lo interno en sus relaciones con la Iglesia y en lo externo haciéndose cargo de la presión británica en 1854, que aspira a ampliar la visión de la tolerancia religiosa.

\section{La tolerancia religiosa, el régimen del patronato y los británicos en la génesis de la república}

Como herencia del siglo precedente, en el transcurso del siglo decimonónico se estimó en la literatura teológica católica, que la tolerancia religiosa podía ser el resultante del relativismo doctrinal o bien de la indiferencia; no obstante, era plausi-

\footnotetext{
${ }^{1}$ Se ha indicado, por Blancarte Pimentel (2001), que la tolerancia no constituiría un concepto de validez universal, ni un valor absoluto pues su definición no es unánime. Kosellek (1993. p. 69) reparó cómo en 1842, Hauréau hizo notar que la noción de "revolución", en su uso latino, implicaba el retorno al punto de partida del movimiento, todo lo contrario, como se asumía en el lenguaje político, éste autor apunta, entonces, que el mentado concepto debe ser asumido como "un concepto universal elástico, que se refiere en cualquier parte del mundo a una cierta precomprensión cuyo sentido preciso está sometido a una enorme variabilidad de un país a otro, de un campo político a otro" (pp. 68-69).
} 
ble que, en consideraciones de bien común del país, para Vera Urbano (2003):"se puede admitir la libertad religiosa de los no católicos en el campo civil (tolerancia práctica o civil), de modo que se salven las justas exigencias del orden público". La autora, en su examen sobre la materia, ha demostrado la disparidad de criterios, entre los partidarios del rigorismo y los adscritos al probabilismo puro, hasta hacerse cargo los teólogos de la distinción de Rousseau, entre tolerancia civil y religiosa, hasta que el jesuita Claude-Adrien Nonnotte, que atendió a la obra de Voltaire, precisó los términos en que debía comprenderse la tolerancia:

\begin{abstract}
"Tolerancia, es la libertad que se deja a cada cual de hablar y de obrar como mejor le parezca, sin que los otros tengan obligación de aprobarlo ni derecho para condenarlo... De esta definición se sigue que la tolerancia justa y racional no cabe sino en asuntos indiferentes, que ni son contra los derechos de la Religión ni contra lo establecido en las leyes".
\end{abstract}

De este modo, los formadores de los eclesiásticos, como eran los manuales y enseñanzas de los teólogos, planteaban consideraciones que, podrían calificarse de casuísticas en cada país para determinar cierta flexibilidad en la materia. Se ha argüido para el caso, que el Papa Pío VI reconoció en 1797 a la República francesa.

Empero, el cambio de la orientación ideológica del Papado alcanzó, en lo que nos importa centrarnos, una postura más intransigente con la Carta Encíclica del Papa Gregorio XVI, de 15 de agosto de 1832, Mirari Vos, Sobre los errores modernos. En el documento de amarras, se cuestiona tanto la libertad de imprenta como la libertad de conciencia. En la nueva directriz, el Papa hace derivar del indiferentismo religioso, la "absurda", "errónea", "locura" libertad de conciencia, que va unida a la "libertad de opiniones, libertad en la oratoria y ansia de novedades" (Gregorio XVI, 1832)2.

Es sugestivo el nexo que se puntualiza entre la libertad de conciencia y su proyección de divulgación o de práctica cívica en la libertad de imprenta.

La Carta Encíclica Mirari Vos, fue acogida en el clero nacional y defendida en las aulas eclesiásticas ${ }^{3}$

Efectivamente, simultáneamente con la situación que veremos en Chile, se

\footnotetext{
${ }^{2}$ Respecto a la libertad de conciencia, refiere: "Este pestilente error se abre paso, escudado en la inmoderada libertad de opiniones que, para ruina de la sociedad religiosa y de la civil, se extiende cada día más por todas partes, llegando la imprudencia de algunos a asegurar que de ella se sigue gran provecho para la causa de la religión". En cuanto a la libertad de imprenta, el documento pontificio es rotundo: Ante la difusión de "monstruos de doctrinas", "errores", la Iglesia sostenía todo lo contrario: "Fue siempre la disciplina de la Iglesia en perseguir la publicación de los malos libros" (par.11).

${ }^{3}$ Sobre la Encíclica Mirari, de 1832, y su recepción en la literatura teológica chilena, Salinas Campos (1976, pp. 36-40).
} 
planteó el dilema en otras naciones latinoamericanas, principalmente en América del Sur, que tuvo repercusiones en los primeros gobiernos republicanos en Chile, desde 1818 hasta 1828. Brasil, bajo el emperador Pedro I, en su Constitución de 1824, mantuvo el dominio de la Iglesia Católica pero la libertad de culto privado para los extranjeros ${ }^{4}$. Un caso más próximo a nosotros el de Argentina, tempranamente se les concedió a los británicos- a través del Tratado de Amistad de 1825, en su artículo 12- la posibilidad de oficiar su culto, pues "gozarán de una perfecta libertad de conciencia celebrando el oficio divino dentro de sus propias casas o en sus propias y particulares iglesia y capillas" (Catanzaro Román, 2015, p. 16).

Hemos indicado que el régimen de patronato fue la institución pilar de las relaciones entre la Iglesia y el Estado. No obstante, las circunstancias del bien común para la nación, en el tema de la tolerancia religiosa civil, volvieron a plantearse con fuerza en los orígenes de la república. En otras palabras, lo que estaba aconteciendo en la sociedad iba a modificar la observancia rigorista del régimen de patronato. A su vez, habrá que apostillar que la aplicación del régimen de patronato por los gobiernos católicos no escapó a las denominadas posiciones regalistas, heredadas de los borbones españoles e incluso por ciertos "excesos" en sus facultades 5

En la discusión de fondo, en el campo civil, había dos modelos contrarios a la Iglesia católica: el de la instauración de la libertad de cultos en los Estados Unidos de Norteamérica, y el establecimiento del estado laico por la revolución francesa. En cuanto al derecho positivo, la Declaración Francesa de los Derechos del Hombre y del Ciudadano, de 1789, consagraba "Nul ne doit étre inquieté pour ses opinions, méme religieuses, pourvu que leur manifestation ne trouble pas l'ordre public établi par la loi", o la Primera Enmienda a la Constitución Federal de los Estados Unidos, de 1791, que declaraba "Congress shall make no law respecting an establishment of religión, or prohibiting the free exercise thereof" (Starck, 1996, p. 17).

En el ámbito filosófico gravitaba en las mentalidades más ilustradas el sesgo anticatólico que provocaba la lectura de John Locke y su Carta sobre la tolerancia, de 1689, y la de Voltaire Tratado sobre la tolerancia. Con ocasión de la muerte de Jean Calas, de 1763. Recordemos que la obra de Rousseau El Contrato Social fue podado en lo concerniente a la religión (las denominadas religión del hombre, del ciudadano y del sacerdote), en la traducción castellana realizada en Buenos Aires.

\footnotetext{
${ }^{4}$ Una visión sintética en Armas Asin (2000).

${ }^{5}$ Lo acontecido con las administraciones católicas republicanas en Perú hasta 1860, como lo indicado en Carpio Sardón (2007, p. 61) y Brahm García (2007). Para Chile, se ha señalado la confluencia de diversas ideologías, desde el regalismo, el galicanismo, la ilustración católica hasta el liberalismo, con relación a los nexos Iglesia y Estado en el periodo anterior a 1830. (Enríquez Agraznar, 2013).
} 
O'Higgins no estuvo ajeno a estos avatares. E incluso en momentos en que se ultima la declaración de independencia duda sobre algunos de sus contenidos, principalmente establecer una prerrogativa tan dominante en materias religiosas, pues:

"Los países cultos han proclamado abiertamente la libertad de creencias. Sin salir de la América del Sur, el Brasil acaba de darnos este ejemplo de liberalismo, e importaría tanto proclamar en Chile una religión excluyente, como prohibir la emigración hacia nosotros de multitud de talentos y de brazos útiles de que abunda el otro continente"(Donoso Novoa, 1946, p. 176) ${ }^{6}$.

Reconoce Donoso Novoa (1946) que otras acciones legales de O'Higgins refrendaron la influencia de la Iglesia en la vida pública nacional.

En el proyecto de Constitución provisoria de 1818, en el Título I su artículo 11 y en el Título II, capítulo único, se recogió lo relativo a la religión (Valencia Avaria, 1986, pp.67-68).

La Constitución, refrendada, como expresaba la convocatoria, por todos los Cabildos del estado, autoridades, corporaciones, jefes, y cuerpos militares, mantuvo inalterable los dos artículos sobre la materia:

"Artículo 11. Todo hombre tiene libertad para publicar sus ideas y examinar los objetos que están a su alcance, con tal que no ofenda... (la) conservación de la religión cristiana, pureza de su moral y sagrados dogmas"

Y el que afirmaba rotundamente:

"Título II. De la Religión del Estado.

Capítulo Único.

La religión Católica, Apostólica, Romana es la única y exclusiva del Estado de Chile. Su protección, conservación, pureza e inviolabilidad, será uno de los primeros deberes de los jefes de la sociedad, que no permitirán jamás otro culto público ni doctrina contraria a la Jesucristo".

Llama la atención la redacción del artículo 11- "religión cristiana"- cuando en el Título II, Capítulo Único, especifica "religión católica, apostólica y romana", en momentos en que se asiste a un contexto de debate de los derechos individuales y cierta impropiedad en el lenguaje ha provocado ambigüedades en el debate público, afec-

\footnotetext{
${ }^{6}$ No puede soslayarse, en este punto, la importante influencia del ambiente londinense y de Francisco de Miranda sobre las ideas de O'Higgins. Castillo Didier (2014); Díaz-Trechuelo (1999). Los Estatutos de la Logia Lautarina (1817), acogían a miembros "distinguidos por la liberalidad de las ideas", refiere Romero (1985, p. 195).
} 
tando a los grandes conceptos de la filosofía del siglo XVIII, como subrayó Collier (2005), que fueron adaptados o, podríamos indicar, domesticados en nuestra prensa.

El pensamiento de O'Higgins se desveló en cuanto al criterio de tolerancia, cuando encaró la solicitud de la colonia inglesa- muy gravitante en Valparaíso y Santiago- respecto a su condición de disidente de la religión oficial. Los ingleses auxiliaban a la novel escuadra naval y su incidencia comercial era patente (Cavieres Figueroa, 1988).

Desde 1817 los numerosos extranjeros arribados a Chile y residentes en Santiago y Valparaíso, principalmente ingleses, no podían enterrar sus deudos en los cementerios localizados al interior de las iglesias católicas. Barros Arana (1892) refiere que los servicios de los ingleses despertaron las simpatías del pueblo e incluso entre las personas influyentes, "que eran más firmes e intolerantes en sus ideas religiosas"(p. 411). Pero, los ingleses habían comenzado su proselitismo religioso con antelación. En 1813, el comerciante inglés John James Barnard, había introducido 150 ejemplares de la biblia protestante en castellano (Baeza Ruz, 2016, p. 18). Una clara manifestación del uso del espacio público de un credo religioso no reconocido que, mediante este ardid, apoyaba las creencias de los suyos en el espacio privado.

Un alto oficial naval inglés, el Capitán Shirreff, "Comandante de las fuerzas de S.M.B. en el Pacífico", encabezó la misiva de 47 extranjeros, protestantes, donde plantearon la situación vejatoria que debían afrontar en las dos ciudades en referencia. En su comunicación, de 30 de noviembre de 1819, los infrascritos plantearon que no "tienen la menor intención de dar su opinión sobre unas instituciones de que no son miembros, i de las cuales el único Juez justo e infalible es aquel Ser que todo lo sabe. Ellos están ciertos de que en varios casos en que han muerto sus hermanos Protestantes en la Ciudad de Santiago, han sido inducidos en la última extremidad, i cuando ya les habian faltado sus facultades físicas i mentales, a abjurar su relijion para ser enterrados cristianamente. I que los restos de otros de sus creencias que se habían mantenido, por conciencia, firmes en sus dogmas, habían sido perturbados después del entierro; i espuestos en la playa en el puerto de Valparaíso... solicitar la interferencia de V.E. para impedir que vuelvan a ocurrir actos semejantes, que chocan a los sentimientos de humanidad, i suplican . Solicitaban adquirir un pedazo de tierra en Santiago y Valparaíso 'para los ritos fúnebres'. No dejaban de mentar los ingleses que la liberalidad del Director Supremo iba a concedérselos, "aun cuando no tuviesen el ejemplar de que se les había concedido lo mismo a los Protestantes en las Provincias Unidas del Río de la Plata, i en el Brasil" (Chile, 1900, pp.177-178) ${ }^{7}$

\footnotetext{
7 "Concesión de permiso a los protestantes para el ejercicio de sus ritos fúnebres. Santiago, 30 de Noviembre de 1819". Habría que interrogarse si era necesario que la misiva fuese encabezada por el "Comandante de las fuerzas de S.M.B. en el Pacífico", lo que denota, por lo menos, un intervencionismo, pues lo hace desde un navío de guerra- extraterritorialidad de la soberanía nacional- a diferencia de los ciudadanos Rev. derecho (Coquimbo, En línea) 2019, 26: e3589
} 
La petición británica encontró asidero en el Senado, controlado por O'Higgins, que "volvió a discutir la ardua e interesante empresa sobre la formación de los cementerios", en base de una antigua cédula de 1804 (Chile, 1900, p. 105) y, en sesión de 26 de agosto de 1819, acordó la conveniencia de sacar de las iglesias el lugar de entierro de los muertos. Los argumentos de salud pública, de contagios y epidemias, de tales entierros en lugares santos, fueron acogidos por los sectores ilustrados y resistidos por el pueblo, anota Barros Arana (1892), pero el tema mayor se presentaría con los no nacionales y profesantes de otro credo.

O'Higgins, mediante el decreto de 14 de diciembre de 1819, reconoció lo "justo que los extranjeros residentes en Chile hagan las funciones funerales de sus difuntos según los ritos de sus creencias. Estos en nada contrarían los de nuestra religión católica. Ellos se han conducido hasta el día con la mejor política, sin mezclarse directa ni indirectamente en materias de creencias. En su virtud, se concede a los suplicantes la licencia que piden para comprar un terreno en esta ciudad i en la de Valparaíso un terreno a propósito destinado a hacer en él sus ritos fúnebres" (Chile, 1900, pp. 178-179).

Sin embargo, el Vicario General del Ejército, Pbro. Casimiro Albano Pereira, consigna Barros Arana (1892), apoyó la iniciativa del Director Supremo, al igual que otros personeros. Otros eclesiásticos se opusieron al mentado decreto ${ }^{8}$.

O’Higgins tuvo que afrontar la disyuntiva de comprender que podía enfrentar al estamento eclesiástico más retardatario- o fidelista a la monarquía- desterrando a algunos, pero no afectar las relaciones con la Iglesia buscando un nexo directo con Roma para proseguir el régimen del patronato. La Misión Muzzi tuvo ese cometido. No obstante, las querellas entre el Estado y la Iglesia se mantuvieron durante la administración de $\mathrm{O}^{\prime} \mathrm{Higgins}^{9}$

El 6 de septiembre de 1821, O'Higgins decretó la compra de un terreno en Valparaíso para construir un Panteón o cementerio. El primer entierro en el cementerio de disidentes fue de un oficial de la Armada chilena.

ingleses avecindados en Valparaíso (que, a su vez, estaban resguardado en su integridad y bienes, por las estaciones navales). Los ingleses, franceses, españoles e italianos, contaron con barcos de guerra surtos en la rada de Buenos Aires y Montevideo, lo que se les denominó estaciones navales. La intervención del capitán Sherrif, demostraría la importancia asignada a Chile, teniendo en Valparaíso, la estación naval del Pacífico (González Pizarro, 1999, pp. 329-336).

${ }^{8}$ Una exposición pormenorizada de la oposición de la Iglesia Católica a los cementerios disidentes, la brindó el obispo José Hipólito Salas y Toro (1872, pp. 24-28), en plena contienda sobre la materia décadas posteriores.

${ }^{9}$ En tal sentido, se ha expresado Stuven Vattier (2016) y Araneda Bravo (1986, pp. 368-378). 
De esta manera, en la práctica, se fue imponiendo por la fuerza de los hechos una tolerancia religiosa por medio de estos actos y también por la circulación de divulgadores de la biblia protestante.

James Thomson inauguró, entre 1818 y 1825, las visitas de los protestantes ingleses en facilitar los textos bíblicos reformistas. Posteriormente, Luke Matthews, misionero británico, encargado de la British and Foreign Bible Society, va a recorrer el subcontinente entre 1826 y 1829 . Visitó Chile, en marzo de 1827, cuando gobernaba el general Ramón Freire, de talante liberal (Baeza Ruz, 2016, p. 10). Apostillemos que, durante la segunda mitad de la década de 1820, las provincias argentinas de Buenos Aires, Mendoza y San Juan, también vivieron un clima de debate en torno a la tolerancia religiosa y la urgencia de ultimar un tratado con Gran Bretaña (Feroni, 2015).

Cabe indicar que esta acción bíblica de los colportores protestantes encontró en otra institución, la British and Foreign School Society, un complemento pedagógico, al insistir en un modelo educacional, el lancasteriano o monitorial, empleando para tales fines, la biblia. En el caso de Thomson a su paso por Valparaíso se identificó como promotor del sistema lancasteriano en vez de colportor. Paralelamente, desde los Estados Unidos de América, se había fundado la America Bible Society, cuya acción de divulgación bíblica, fue reconocida por los ingleses.

En una carta de 1821, Thomson precisó el obstáculo de ser reconocido como inglés o británico, por la asociación mecánica de protestante:

"Al hablar de religión es común el uso de las palabras cristiano y protestante en contraposición la una con la otra, significando mediante la primera a ellos mismos o a los católicos en general, y por la segunda, a los ingleses o protestantes en general" (Baeza Ruz, 2016, p. 14).

En 1824, el Papa León XII en su encíclica Ubi Primun criticó la labor de la Sociedad Bíblica Británica y sus perniciosos libros (Baeza Ruz, 2016, p. 19).

El arribo oficial del agente consular británico, en 1823, con asiento en Valparaíso-escribe Donoso Novoa (1946)- vino con instrucciones de conseguir para los súbditos de la S.M. "la tolerancia de sus opiniones religiosas, el libre ejercicio de su culto y la celebración de sus ceremonias fúnebres" (p. 201).

El objetivo alcanzado por el agente consular y la colonia inglesa se materializó rápidamente. La Iglesia Anglicana comenzó sus servicios en 1825 en casa de Thomas Kendall. En 1837 los ingleses solicitaron al obispo de Exeter abrir una iglesia en Valparaíso. Era una comunidad de 500 miembros. El gobierno chileno accedió a la construcción "de una escuela, donde podrían celebrarse servicios religiosos" (Marsh, 2011, 
pp. 240-241). El funcionamiento fue constatado por el ministro del Interior, Joaquín Tocornal, ese mismo año. Apunta Donoso Novoa (1946) que una discrepancia entre ingleses y norteamericanos dio lugar a la creación de una segunda iglesia protestante, a la que los norteamericanos llamaron "Unión".

El jurisconsulto Juan Egaña terció en la disputa sobre la tolerancia religiosa, en 1825, al distinguir entre la "libertad de pensar" y la de "propagar pensamientos incendiarios y corruptores", e incluso a oponerse a la inmigración si esto se traducía en la llegada del protestantismo u otra ideología que atacara la religión católica.

Hubo un grupo, al igual que en España, de católicos que acogieron determinados presupuestos del liberalismo y la modernidad que José Antonio Maravall tipificó, para el caso peninsular de "católicos liberales" (González Manso, 2014) ${ }^{10}$. En América Latina, hubo también una facción del "catolicismo masón", en Uruguay.

En la convergencia en pro de la tolerancia religiosa se van a encontrar los liberales de ideas más avanzadas y los pertenecientes a las logias masónicas, que vieron en las iglesias protestantes, la coexistencia de un credo religioso con los ideales de progreso y modernidad y la exaltación de un libre pensamiento, en su cuestionamiento de la exclusividad católica ${ }^{11}$.

La Constitución de 1828 en gran medida reflejó tales aspiraciones de mantener el patronato y de modo tangencial, no subrepticia, el controvertido artículo 4: "Nadie será perseguido, ni molestado por sus opiniones privadas"12

\footnotetext{
${ }^{10}$ En este lineamiento se ha sostenido que hablar del liberalismo católico no sería tan irracional, siguiendo la sugerencia de Mario Góngora de hablar de una "ilustración católica". Fernández Sebastián (2011).

11 Ver: Bastian (1995); Bastian (1990); Chocano Mena (2010). El caso más ilustrativo se dio en México en la década de 1860 en tiempo de la lucha de los liberales contra la monarquía de Maximiliano I, cuando Benito Juárez apostó por un protestantismo que se "mexicanizara", fracasando en su intento. Confrontar Zea Aguilar (1943).

${ }^{12}$ La resistencia del clero a esta Constitución, al decir de Errázuriz Zañartu (1861), no fue por el mentado artículo, sino por "el ataque a sus temporalidades" (p.33). Un documento contemporáneo a la Constitución ventiló el artículo 3, que declaraba a la religión católica, apostólica y romana como la oficial con exclusión del ejercicio público de cualquiera otra, y el artículo 4. En el diálogo entre un Ciudadano y un Diputado, (Anónimo, 1828) el último le explica que el artículo 3, al hablar de exclusión, "...no se les prohíbe el ejercicio privado de ella, es decir, el que cada uno en su casa pueda ocultamente y en secreto ejercitarla como quiera, y practicar sus ritos y ceremonias...esa cláusula no presenta dificultad alguna; pero sí, la presenta i mui grave la del artículo que sigue (el 4). Por todo el contesto (sic) y el artículo antecedente se infiere, que cuando se dice opiniones privadas se habla de las opiniones en materia de religión, las que si son contra algún dogma de la verdadera, deberían llamarse errores hablando con propiedad... Opinión privada es aquel modo de sentir o pensar que el hombre tiene para sí i sobre cualquier materia, pero que no le sirve de regla para sus acciones y conductas públicas, ni lo propala delante de personas que pueden atestiguarlo y probarlo, opinión pública por el contrario, cuando el hombre se vale de ese modo de sentir que tiene en su interior, para reglar su conducta y acción pública, o no trepida en vertirse (sic) y declararse delante de alguna o muchas personas que pueden probar y atestiguar su modo de pensar...las opiniones privadas y ocultas no están sujetas a la inspección y jurisdicción del hombre, sino solo a la de
} 
Sin embargo, el triunfo conservador en Lircay, en 1829, y la reforma de la Constitución de 1828, ahondó la exclusividad de la Iglesia Católica. Y esto comenzó con el proyecto ceremonial que aprobó el Congreso de 1831, donde el Presidente de la República debía prestar el siguiente juramento:

\begin{abstract}
"Juro por Dios y estos santos Evangelios conservar y sostener la religión católica, apostólica, romana, observar y hacer cumplir la Constitución y leyes del Estado. Así Dios me ayude y sea en mi defensa, y si no me lo demande" (Donoso Novoa, 1946, p. 189).
\end{abstract}

La discusión de asociar las opiniones privadas al espacio doméstico o privado y las expresiones públicas al espacio público que, comúnmente, podría acogerse de modo sencillo y lógico, no era tan simple. La complejidad radicaba, a nuestro entender, en dos ámbitos que la carta encíclica Mirari Vos había denunciado y que los liberales, desde posiciones contrarias, acogían en el fondo:

1. No se podía disociar la conexión de la libertad de conciencia (opinión) con la praxis de ésta (libertad de imprenta) que, en el caso, que visualizó O'Higgins, era proyectar esto en el rito fúnebre de un credo disidente al católico, o en el campo de la libertad de opinión en la materialización de la libertad de imprenta,

2. Lo racional que podía entenderse, en que todos proveyendo de un mismo tronco-el cristianismo- todo profesante del protestantismo, sin perseguir alterar las instituciones de la confesionalidad del Estado, debería respetarse su voluntad última y no procurar violentarse ésta, mediante la abjuración de su fe, para lograr una sepultura cristiana. Esto mismo, se planteaba, en los hechos, que los colportores protestantes repartían sus biblias a sus seguidores y éstos, en el uso de su libertad de conciencia, mediando el tránsito de la biblia por el espacio público, podían seguir comulgando intramuros de sus casas, con los elementos necesarios de su fe.

Esto para la Iglesia Católica era difundir entre las clases populares, la degeneración de su feligresía, por medio de una propaganda, accesible, la biblia en español, donde cada individuo podía asumir su interpretación.

Dios, que es único que Intuctur Cor... adviértase cuidadosamente que el artículo habla solo de las opiniones privadas, porque el que profese y tiene en público opiniones contrarias a la religión está sujeto a la jurisdicción del magistrado, y debe ser castigado por el gobierno civil como perturbador de la tranquilidad pública...". (pp. 27-29). 


\section{La Constitución de 1833 , la normalización de las relaciones di- plomáticas con Europa y el debate sobre la tolerancia religiosa}

La nueva Constitución de 1833 reforzó el patronato y la hegemonía de la Iglesia Católica.

No se ha mentado lo suficiente, a nuestro criterio, sobre la interpretación del artículo en que se consagraba la religión única, en momentos en que se edificaba la nueva institucionalidad. Sin entrar en lo irregular, que denunciaba Errázuriz Zañartu (1861), la resolución de la reforma de la Constitución de 1828, nos interesa revisar lo que los constituyentes discutieron sobre lo que iba a dar forma a la Constitución de 1833.

En la sesión 17, de 21 de noviembre de 1831, se aprobó por unanimidad el artículo 6, "sin discusión alguna", en la forma siguiente: La Religión de la República de Chile es la Católica, Apostólica, Romana, con exclusión del ejercicio de cualquier otra.

El debate que suscitó esto es interesante de observarlo. Refieren las actas que:

"El señor Vial Formas hizo indicación para que se pusiese en seguida el artículo de la Constitución de 1828, que dice: 'Nadie será perseguido ni molestado por sus opiniones privadas', i después de considerarlo, se dejó para segunda discusión" (Letelier Madariaga, 1901, p. 209).

En el anexo 59, de la sesión en cuestión, se retoma el debate, sobre el artículo 4 de la Constitución de 1828:

"El Sr. Vial Formas... espuso, es conveniente a los chilenos i a los extranjeros porque sin él cualquiera querrá erigirse en juez de las opiniones ajenas. No basta que el artículo que acaba de aprobarse diga que solo se prohíbe el culto público, porque el no deja suficiente garantía al modo de opinar de cada uno i si a ninguno puede compelerse a seguir esto o la otra religión, tampoco puede ser molestado por las opiniones que tenga a este respecto. Mas, no sucedería esto, si no se pusiese en la Constitución el artículo que se ha suprimido, i no se daría seguridad alguna a los extranjeros que vinieren a vivir entre nosotros" (Letelier Madariaga, 1901, p. 210).

Vial Santelices refutó argumentando que solo excluye el ejercicio público de cualquiera otra religión. 
Vial Formas argumentó que todo esto y "el de la opinión privada que es acaso el principal, i que manifestándose las opiniones no solo por las palabras sino también por los hechos, admitido, como no podía dejar de admitirse, el principio de que a ninguno puede obligársele a profesar religión alguna contra su propia voluntad i no podía dejarse a los hombres expuestos a que se les obligase, como ya se ha visto, a pertenecer a otra creencia de una que tienen, habiendo causado un estravío semejante i males de la mayor consideración. Que convendría en que el artículo no se extendiese a las opiniones políticas" (Letelier Madariaga, 1901, p. 210).

Gandarillas (Manuel), en su intervención, adujo que "so pretexto de opiniones privadas i conducir así a otros a la sedición, que la opinión privada no era otra cosa que la creencia que el hombre tiene para si o el dictamen de la propia conciencia, sea recto o errado, el artículo no tiene otro objetivo que evitar las persecuciones por esta creencia o doctrinas, que si tratase de una Constitución para Inglaterra, Francia, Estados Unidos $u$ otros países en donde se halla establecida la tolerancia, creería desde luego que el artículo era superfluo, pero, siendo para un Estado que había sido dependiente de la España, $i$ que de ella había tomado también las preocupaciones, no podía mirarlo sino como necesario" (Letelier Madariaga, 1901, p. 2010).

Vial Santelices señaló que aprobado el artículo 6, "en Chile, no hai libertad de religión, que siempre se ha recibido i tratado como hermanos a los extranjeros de diferentes comuniones, sin que hayan decaído de la estimación que merezcan por causa de su profesión religiosa; que se ven frecuentes dispensas para matrimonios con católicas $i$ nada hai en contra de una racional tolerancia, que si se quiere será disposición legal de que se deduzca, el artículo aprobado es suficiente; pues, prohibiendo solo el culto público, no deja arbitrio alguno para introducirse a juzgar de los sentimientos privados de los hombres, de su estado interior en punto de religión".

El señor Vial del Río (Juan de Dios) afirmó: "Que privado no es solo aquello que uno conserva en su interior sino lo que espresa delante de pocas personas i principalmente en el recinto de su casa".

Interesa destacar que las argumentaciones apuntan:

a) En pro de la libertad de opinión y su no persecución de lo que se expresa, se leía correctamente en cuanto atendía a las materias religiosas;

b) Que se puede desprender, en los hechos, un criterio de la existencia de matrimonios mixtos y una "racional tolerancia" que, a mi juicio, tiene en vista lo acontecido en la década de 1820, respecto de los protestantes, y que va a continuar sin hacer mella en la institucionalidad que protege a la religión católica, apostólica y romana; 
c) Por un lado, la admiración a los referentes europeos, Inglaterra y Francia, donde existe la tolerancia religiosa, y la inmigración extranjera- extracontinental - que deberá ser garantida en su credo religioso y, por otro, la herencia cultural hispana, leída como la preponderancia de la Iglesia Católica, con el patronato, y la no tolerancia a la disidencia en esta materia.

El artículo 6, correspondió finalmente al artículo 5 de la Constitución de 1833.

Ya en vigencia la Constitución de 1833, uno de los epígonos del liberalismo nacional, José Victorino Lastarria, volvió a cargar las tintas sobre la hermenéutica del artículo 5.

Lastarria Santander (1856), con mucha honestidad intelectual, apuntó que "por lo que toca a nosotros, contemporáneos i adversarios francos de esa política" (alude la Constitución de 1833 y su régimen institucional) examina el precepto constitucional, siguiendo de cerca a Felicité Robert de Lamennais, un católico liberal francés, de mucha influencia, condenado en la carta encíclica Mirari Vos, de 1832.

Lastarria, en el desmontaje del andamiaje del artículo, concluyó:

1. La religión "no está sometida a la acción del derecho, i por tanto no puede ser objeto de la Constitución. Consistiendo esta unión en las relaciones que se derivan de la naturaleza de Dios i de la del hombre, la lei no podría avanzarse a tocar esas relaciones sin atacar la libertad de la inteligencia i la espontaneidad del corazón" (Lastarria Santander, 1856, p. 11).

2. Que la manifestación del sentimiento religioso en los países católicos, recae en una institución públicamente organizada, que es la Iglesia, por lo que se sigue que el "art.5 de la Constitución no es una prescripción de derecho referente a la relijion considerada en toda su pureza, ni afecta en lo menor al sentimiento relijioso de los chilenos, ni se dirije a la libertad natural de que goza el hombre en sus relaciones con la Divinidad. Lo único a que se dirije esta disposición es a la Iglesia, porque esta es la única que, en su carácter de institución existente en la sociedad, está en relación con el derecho, con la lei" (Lastarria Santander, 1856, p. 12).

3. Fue innecesario que en el artículo en referencia se declare "La religión de la República de Chile es la Católica, Apostólica, Romana...para que se supiera que aquella era la relijion existente: la sociedad no tenía necesidad de esa noticia, ni el Estado podía ceñirse exclusivamente a reconocer el hecho, pues que el Estado, como encargado de la aplicación del principio del derecho, tiene el deber de suministrar a la relijion, considerada como institución, las condiciones de su existencia i de su desarrollo, i de reglar sus relaciones esternas... La segunda parte (del artículo) con exclusión del ejercicio público de cualquiera otra...cualquiera 
otro culto público está por consiguiente fuera de la lei no puede reclamar para su existencia i relaciones el amparo del Estado... Ia relijion considerada como institución"(Lastarria Santander, 1856, p. 13).

Para el tribuno liberal la paradoja era evidente:

"Dejar al hombre la libertad de creer, prohibiéndole la de manifestar lo que cree, es atacarle esa libertad: es lo mismo que si le permitiéramos pensar como quisiera en política i le prohibiéramos el hablar i el escribir sus pensamientos. Semejante restricción es la negación de lo que se concede" (Lastarria Santander, 1856, p. 14).

En consecuencia, o se aplicaba rigurosamente el artículo 6 sin excepciones o, no se observaba, dejando en los hechos la libertad de conciencia.

Toda esta discusión no se condijo con la realidad de las relaciones diplomáticas del Estado de Chile, que en el periodo concretó determinados tratados de amistad. Y simultáneamente, mientras se desarrolla la Convención que dará lugar a la nueva Constitución de 1833, se firma con los Estados Unidos de América, la "Convención General de Paz, Amistad, Comercio y Navegación", el 16 de mayo de 1832 y el 1 de septiembre de 1833, la que fue canjeada el 19 de abril de 1834 y promulgada el 12 de octubre de 1834.

Se estipula en el art.11, lo siguiente:

"Se conviene igualmente en que los ciudadanos de ambas Partes Contratantes gocen la más perfecta y entera seguridad de conciencia en los países sujetos a la jurisdicción de una u otra, sin quedar por ello expuestos a ser inquietados o molestados en razón de su creencia religiosa, mientras que respeten las leyes y usos establecidos. Además de esto, podrán sepultarse los cadáveres de los ciudadanos de una de las Partes Contratantes, que fallecieren en los territorios de la otra, en los cementerios acostumbrados, o en otros lugares decentes y adecuados, los cuales serán protegidos contra toda violación o disturbio"(Bascuñán Montes, 1894, p. 34).

El plenipotenciario por Chile fue Andrés Bello, que había redactado la primera obra sobre el derecho internacional en 1832, nombrado Oficial Mayor del Ministerio de Relaciones Exteriores, desde 1834, y uno de los consejeros en esta materia durante el periodo ${ }^{13}$. Gravitó la experiencia londinense, su amplitud de criterio-tradujo a

\footnotetext{
${ }^{13}$ Sin embargo, en las tratativas preliminares conducidas por Silverio Ochagavía, en representación de Chile, y por David A. Sharkweather, por los EE.UU. se había consensuado ciertos pormenores relativos Rev. derecho (Coquimbo, En línea) 2019, 26: e3589
} 
Voltaire- y el sentido de lo que se ha estimado su filosofía de la "moderación", que se puede apreciar en este primer tratado que, ampliamente, satisface los requerimientos de los disidentes a la fe católica. Lo de los cementerios había sido despejado en $1819^{14}$. Y, a nuestro entender, no estaba solo en estas apreciaciones donde la mentalidad ilustrada (Bravo Lira, 1992) dominaba a las personalidades más influyentes del nuevo régimen, desde Diego Portales, que no posaba como católico observante pero sí veía a la Iglesia como pilar del orden y ascendiente sobre las clases populares. La otra figura, Mariano Egaña, era reticente al retorno de la Compañía de Jesús, precisamente por su arraigado regalismo, o celo por las facultades del Estado.

El Tratado de Amistad, Comercio y Navegación entre Chile y Francia, firmado el 15 de septiembre de 1846 y el 30 de junio de 1852, canjeado el 12 de mayo de 1853 y promulgado el 17 de mayo de 1853, fue más restrictivo en lo referente a la "libertad de conciencia", que se estableció en el artículo 4:

"Los ciudadanos y súbditos de los dos estados gozarán respectivamente de la más completa libertad de conciencia, y podrán ejercer su culto de la manera que lo permiten la Constitución y las leyes del país en que se encuentra" (Bascuñán Montes, 1894, p. 149).

Pero, estas situaciones excepcionales que se planteaban en el campo de las relaciones internacionales, también prosiguieron al interior del territorio. En 1837, Jorge Huneeus, denunciaría en el Congreso en julio de 1865, que dos ministros del gobierno de Prieto, Joaquín Tocornal y Mariano Egaña, presenciaron en Valparaíso "el establecimiento de la primera capilla protestante en aquel pueblo, sin que les ocurriera ni por un momento que aquello era una infracción constitucional" (Donoso Novoa, 1946, p. 192).

\footnotetext{
a las materias religiosas, que condensaba el artículo 14 los nacionales no "serán molestados, perseguidos o inquietados por causa de sus creencias religiosas, sino que gozarán en ellos perfecta i entera libertad de conciencia.... Si en la ciudad, villa o distrito en que residan los ciudadanos de cada una de las partes contratantes, no hubiere cementerio establecido para el entierro de los de su creencia relijiosa, podrán con el consentimiento de las autoridades locales superiores i en el lugar elejido con aprobación de dichas autoridades establecer un cementerio. Este cementerio, i los entierros que se hagan en él, se sujetarán a las reglas de policía que las autoridades civiles de uno i otro país dictaren respectivamente". El documento, sin datar, proviene del Ministerio de RR.EE. de Chile. Copiador de correspondencia enviada a los Agentes Diplomáticos y Consulares extranjeros. (1850).

${ }^{14}$ Bello López (1832), planteó que este derecho tenía dos clases de sanciones: la religiosa y la de la vindicta humana; la "relijiosa (que) consiste en las penas con que la justicia divina amenaza castigar la inhumanidad, la estorsión, el fraude, todas las violaciones a la lei natural...ejerce igual influencia sobre los jefes de las naciones que sobre los individuos privados; pero no así la segunda" (p. 2). Importa detenerse en el valor que asigna Bello al "fuero de la conciencia" de una nación (p.3). Por este valor, anotó, una nación está "obligada" a franquear sus puertos al comercio de las otras, sin que esto le acarree males.
} 
La llegada de David Trumbull, el 25 de diciembre de 1845, en circunstancias que "había un solo pastor evangélico en toda la costa del Pacífico" (Donoso Novoa 1946), constituyó una prueba más para el Estado y para la Iglesia, respecto a la observación del patronato ${ }^{15}$. Si se sigue el criterio de Lastarria Santander (1856) se pasaba de la libertad de conciencia, que resguardaba la religión de las personas, a la instauración de una institución, la Iglesia Presbiteriana, que transgredía completamente el régimen de patronato, en la modalidad que lo entendía la Iglesia y en la forma como lo interpretaba Lastarria Santander (1856).

Para nadie era extraño que las iglesias protestantes o evangélicas, simpatizaban con las posturas de los liberales y con toda acción política que apoyara la libertad religiosa ${ }^{16}$

Chile, además, había determinado bajo el gobierno del general Manuel Bulnes (1841-1851) dar un avance en el campo de la cultura, abriendo la Universidad de Chile, promulgando la legislación de imprenta, abrir las puertas a la inmigración extranjera, especialmente la europea, que fue incentivada por el Estado durante la administración de Manuel Montt, principalmente la alemana para la colonización del extremo sur del territorio. No es necesario comentar el tema religioso ligado a tal inmigración y de qué manera el Estado se desatendió del arribo de alemanes luteranos. Lo que importaba como bien común era la ocupación de esos parajes.

\section{Montt en la encrucijada de las relaciones entre el Estado y la Igle-} sia

El gobierno de Manuel Montt no fue tranquilo en su orden interno. A diferencia del gobierno de su antecesor, las revoluciones de 1851 y 1859 marcaron el rechazo al régimen político y, en especial, a su administración.

En el terreno latinoamericano la materia que nos ocupa fue cada vez más álgida. Mientras Colombia no encontraba una fórmula para las relaciones Iglesia y Estado, oscilando con un patronato entre 1824 a 1853, trajo la separación de la Iglesia y el Estado que se prolongó hasta 1885. Liberales y conservadores mantuvieron nueve guerras civiles en el siglo (Ortíz Mesa, 2013). Argentina, desde 1853, había tomado una dirección proclive a la libertad religiosa, mientras Uruguay, desde que José Arti-

\footnotetext{
${ }^{15}$ Serrano Pérez (2008, pp. 183-185) ha planteado que el espacio público para el Estado y la sociedad era considerado privativo de la Iglesia Católica y el ejercicio de la libertad de conciencia apuntaba a relacionarse con el espacio privado, ligado principalmente con la casa habitación. Cuando Trumbull, en 1854, comienza a gestionar la construcción de su iglesia, que se levantó en el cerro Concepción de Valparaíso, el gobierno transó con Trumbull: "el templo debía ser cubierto con un tabique y la fachada no podía ser visible desde la calle, no podría tener campanario y el culto debía celebrarse en el mayor silencio". También en Serrano Pérez (2005).

${ }^{16}$ Nuevamente estos temas han sido abordados por Concha Contreras (2013), Pacheco Carreño (2008), y Pacheco Carreño (2011).
} 
gas abogara en 1813 por un proyecto constitucional que declarara la libertad de cultos (Romero, 1985, pp. 15.18), mantuvo dicho criterio en la Constitución de 1830 hasta que en 1858 se suscite el problema con los jesuitas que derivaron en su expulsión al año siguiente (Schurmann Pacheco y Cooligham Sanguinetti, 1996, pp. 120-121) ${ }^{17}$.

La ofensiva del arzobispo Rafael Valentín Valdivieso concretada en la fundación de La Revista Católica, en 1843, entre otras acciones, se vio puesta a prueba en el decenio de 1850, a nuestro entender, el más fundamental que signó los destinos de lo que vendría a continuación hasta concluir el siglo.

La propia publicación católica dio cuenta de disturbios, como ser la quema del Edicto del Arzobispado de 21 de noviembre de 1853 en Copiapó, por una multitud de cuatro mil personas, el peligro protestante de la inmigración alemana en Valdivia, llegando a sostener la amenaza para la unidad nacional y el temor a la secesión de la localidad y su zona, etc ${ }^{18}$, lo cual no era del todo inesperado, por la convulsión con que había iniciado Montt su gobierno. A esta situación en el campo políticosocial, se debe agregar la tirantez de las relaciones entre la Iglesia y el Estado por una serie de acontecimientos, como ser el juramento civil de los obispos, condenado por el Papa Pío IX el 6 de junio de 1854, la denominada "cuestión del sacristán" entre enero y octubre de 1856. En cuanto al Código Civil, determinados obispos vieron un marcado "regalismo" en su redacción cuando no ideas secularizadoras, aun cuando no formularon objeciones mayores (González Pizarro, 2006b). La misma discusión entre el Pastor Trumbull y la autoridad eclesiástica católica, hacia fines de la década, condujo a la ley interpretativa del artículo 5 de la Constitución en $1865^{19}$.

A esto se sumaba la percepción de los prelados chilenos que el catolicismo nacional se vivía de un "modo distinto", pues estaba insuflado por ideas racionalistas, liberales, claramente modernistas, que incidían en las decisiones gubernamentales. El arzobispo Rafael Valentín Valdivieso denunció esto en julio de 1856 al obispo de Concepción, respecto al Código Civil, sus "autores (sic) semejan a ciertos sujetos que pasan por mui católicos, pero que, como regalistas, se extasían con los Condes de Aranda i Campomanes, i como políticos, admiran las conquistas de la revolución francesa i las aplauden" (González Pizarro, 2006b, p. 21). Y esto era dominante en el periodo de Montt, un hombre que, al decir de Bravo Lira (1992), estaba imbuido de los ideales de la llustración. Entre los jóvenes conservadores que se van a destacar, como Ramón Sotomayor Valdés, se reconocía como un "racionalista católico" y firme partidario del regalismo (Brahm García, 1992). Pudo pesar también- en línea con los ideales ilustrados, racionalistas y liberales presentes en la esfera del gobierno- la construcción de la imagen del país ${ }^{20}$.

\footnotetext{
17 También González Pizarro (1989), señala que hubo un nexo entre la inmigración francesa y el fortalecimiento del catolicismo masón, adversarios de la influencia de la Compañía de Jesús, que restaurada en 1858 fue expulsada al año siguiente.

18 Todo esto puso de manifiesto la "disonancia entre lo que prescribía la Constitución Política en las relaciones entre el Estado y la Iglesia y la postura del gobierno de Montt ante este resquebrajamiento en la sociedad civil de la confesionalidad del Estado" (González Pizarro, 2006).

19 Sobre la concatenación de sucesos que desencadenaron el conflicto hasta 1865, Serrano Pérez (2008); Donoso Novoa (1946) y Estellé Méndez (1967).

${ }^{20}$ La elite política procuró la construcción de una imagen país que debía proyectar una nación guiada por los ideales del progreso institucional y el desarrollo material científico, que lo destacaba en el
} 
Este cúmulo de acciones e ideas apreciado en su globalidad por los liberales y considerado como un todo por el Papado, tuvo un enfrentamiento general por la Iglesia, sea en el campo de la modernidad, de los derechos subjetivos de todo orden, que se reflejó en la Encíclica de Pío IX (1864). Y esto marcó todo lo que restaba del siglo XIX ${ }^{21}$.

\section{Los documentos de la diplomacia británica y el Tratado de 1854}

En este contexto se tienen que leer los dos documentos ingleses concernientes a la libertad de conciencia, donde se dieron argumentos que, sin duda, pesaron en la inteligencia de los hombres de gobierno, precisamente, haciendo notar los beneficios en que redundarían para la nación lo solicitado. En uno de ellos se indica, de modo indirecto, lo consignado en la materia por Adam Smith, en cuanto a que, "donde existe la tolerancia relijiosa, no solo crece la moralidad i felicidad, sino que han progresado la prosperidad material del país, en el primer caso por el culto tributario a Dios conforme a los dictados de la conciencia sin restricción alguna, i en el segundo por el estímulo habilidad e industria extranjeras i este último es más especialmente aplicable a Chile que lucha honrosamente a la vanguardia de la civilización sur americana i en el espíritu de empresa". O las palabras que apuntan a resaltar, el criterio "civilizatorio" con la fusión del modelo del "liberalismo", tan caro en la mentalidad de la elite política y social chilena: "Semejante medida hace honor al Gobierno de Chile, prueba los prin-

concierto latinoamericano. Esto se evidenció en las instrucciones de Mariano Egaña a Claudio Gay cuando acometa la redacción de la Historia Física y Política de Chile, publicando su primer tomo en 1844 y el último en 1871, de un total de 21 volúmenes. Esto, sumado al Observatorio Astronómico, los Anales de la Universidad de Chile, mostraban a una nación acorde con los avances de la ciencia, y en el derrotero de las naciones "civilizadas", lo cual debía, a juicio del gobierno, manifestarse en el plano de las libertades individuales, sea de opinión como de creencia, que lo ponía en la dirección de los países más relevantes del orbe: Inglaterra, Francia, Estados Unidos de Norteamérica (González Pizarro, 1990). Subercaseaux Sommerhoff (2011) ha precisado de qué manera los referentes europeos mantenidos por un sector mayoritario de la elite, comienzan a ser reemplazados por los Estados Unidos de Norteamérica, en algunos liberales, como Lastarria (lo mismo aconteció en América Latina). El propio arzobispo Valdivieso, al bendecir el ferrocarril de Santiago a San Bernardo, en septiembre de 1855, ensalzó el genio y la ciencia de Newton, siéndole recordado que el científico inglés había sido anatemizado. Theophilos (1863, pp. 19-20).

${ }^{21}$ En Quanta Cura además de impugnar las doctrinas del regalismo, el naturalismo, el comunismo y el socialismo, anexó el Syllabus "de los principales errores de nuestro siglo", que debían ser "absolutamente tenidas por reprobadas, proscritas y condenadas", donde en lo pertinente a nuestro tema, espigamos: XVIII. El protestantismo no es más que una forma diversa de la misma verdadera Religión cristiana, en la cual, lo mismo que en la Iglesia, es posible agradar a Dios; LXXVII. En nuestra edad no conviene ya que la religión católica sea tenida como la única religión del estado, con exclusión de otros cualesquiera cultos; LXXVIII. De aquí que laudablemente se ha establecido por la ley en algunos países católicos, que a los extranjeros que vayan allí, les sea lícito tener público ejercicio del culto propio de cada uno; LXXIX. Es sin duda falso que la libertad civil de cualquiera culto, y lo mismo la amplia facultad concedida a todos de manifestar abiertamente y en público cualesquiera opiniones y pensamientos, conduzca a corromper más fácilmente las costumbres y los ánimos, y a propagar la peste del indiferentismo". Esto demostraba el cambio experimentado por el Papa Pío IX entre 1846 a 1864, cuando se comenzó a motejar de "ultramontana" su visión del mundo. (Martina, 1974, pp. 189-192). 
cipios liberales que caracterizan su política, i puede mirarse como el presajio de un orden de cosas más tolerante por lo que respecta a las materias religiosas en general"

Importa subrayar como se involucró el ministro Antonio Varas- un defensor del regalismo- en la gestión del Tratado con Gran Bretaña, a través de minutas reservadas al diplomático inglés, que se hace constar en el segundo documento, y cómo debía buscarse la tolerancia religiosa en un marco constitucional que lo prohibía. Varas se desempeñó como ministro del Interior y Relaciones Exteriores, durante todo el primer gobierno de Montt.

El primer texto señala lo siguiente:

"Legación Británica

Santiago, Enero 22 de 1854.

Señor:

Tuve el honor de recibir en la tarde de ayer, la cláusula que S.E. propone debe sustituirse en el Tratado en lugar del artículo 13 en el proyecto de tratado propuesto por el Gobierno de S.M relativo a la tolerancia i culto relijioso. Antes de entrar a tratar de este asunto deseo reconocer con agradecimiento el espíritu liberal i cortés que ha manifestado Ud. individualmente al discutirlo durante las entrevistas que he tenido el honor de sostener con Ud. Al mismo efecto, debo sentir profundamente que el artículo propuesto por S.E. no esté de acuerdo en los puntos más importantes i materiales con el formulado por el Gobierno de S.M. Este desea estipular que los ciudadanos de las dos Partes Contratantes como ramas de la misma gran familia cristiana se les permita en uno i otro país construir sus iglesias i adorar a Dios conforme a la creencia en que han nacido i han sido educados, i si las preocupaciones de la especie humana no permiten que los muertos estén los unos al lado de los otros en su último lugar de reposo, que se les permita al extranjero un cementero en el que puedan honrarse sus restos con las acostumbradas demostraciones de afecto i respeto, i en el que pueda ofrecerse un público tributo de adoración i sumisión al Todopoderoso Dispensador de la vida.

Estos privilegios han sido repetidas veces concedidos por tratados entre países católicos romanos i protestantes, igualmente en Europa i América, i no es demasiado asegurar que en donde existe la tolerancia relijiosa, no solo crece la moralidad i felicidad, sino que han progresado la prosperidad material del país, en el primer caso por el culto tributario a Dios conforme a los dictados de la conciencia sin restricción alguna, i en el segundo por el estímulo habilidad e industria extranjeras i este último es más especialmente aplicable a Chile que lucha honrosamente a la vanguardia de la civilización sur americana i en el espíritu de empresa. El emigrado más apreciable desde el jénero 
de la más alta reputación hasta el más humilde artesano, debe encontrarse entre aquellos que dan la mayor importancia a una creencia relijiosa conforme a su conciencia, i que no quiere establecerse en un país en donde es prohibido su ejercicio público. Confío sinceramente que no está distante el día en que Chile adoptará a este respecto una política más conforme con sus instituciones libres.

Fui informado por S.E. que el artículo $3^{\circ}$ de la Constitución chilena que declara que no habrá culto público, excepto el católico romano, era un obstáculo para la introducción de la cláusula del Gobierno de S.M. relativa a la erección de iglesias, i, al mismo tiempo que Ud. concedía que este no era aplicable a los cementerios manifestaba que su repugnancia para adoptar en parte de la cláusula relativa a ellos, nacía de la idea de que el 'permiso para enterrar a los muertos' hacía presumir la intolerancia la que sería desagradable a este país, i la cual no existe. Encuentro esta idea reproducida en la nota privada de S.E. del día 20. Por consiguiente, llamo respetuosamente la atención de S.E. a la cláusula propuesta por el Gobierno de S.M. que estipula no solamente el permiso para 'enterrar a los muertos', cuya negativa envuelve el barbarismo, sino los privilegios más caros a los que sobreviven 'de las acostumbradas formas i ceremonias religiosas'. La policía o disposiciones sanitarias respecto de la conducción de los cadáveres en la noche, serían por consiguiente cumplidos, los oficios relijiosos se limitarían al recinto del cementerio.

Al hacer estas observaciones desearía que S.E. no infiriese, que desconozco las facultades que se han concedido por el Gobierno Chileno al culto protestante en Valparaíso, como también respecto de un cementerio, i estoi además extremadamente agradecido por la promesa que S.E. me hizo, de que las mismas facilidades se harían extensivas a otros funcionarios de la República donde existiesen comunidades protestantes i por la bondadosa oferta de comprar terrenos para un cementerio para los protestantes residentes en Santiago, pero no puedo dejar de expresar mi deseo de que esta jenerosa política se hiciese pública por el Tratado, en donde estoi seguro hallaría la sincera aprobación i el apoyo de la parte educada i más influyente de esta nación. Por consiguiente, espero que el Gobierno de S.E. el Presidente consentirá en adoptar la cláusula propuesta en el proyecto, o al menos una más extensiva que la que acabo de recibir.

Tengo el honor de ser

Señor de S.E. obediente humilde servidor

E.A.J. Harris

Sr. D. Antonio Varas". (Notas enviadas por el Gobierno y los Agentes de S.

M. Británica en Chile al Ministerio de RR.EE. de Chile, 1853) 
El segundo documento refiere:

"Legación Británica

Santiago, Diciembre 1855

Señor:

La hospitalidad que se ha acordado a los súbditos británicos durante el transcurso de cuarenta años, por el gobierno i los ciudadanos de Chile, formaba un notable contraste con ese espíritu de intolerancia que negaba al extranjero un lugar de descanso para sus restos mortales cuando plugiere a la Divina Providencia llamarlo.

Una sentida representación firmada por nuestro compatriota, el bizarro capitán Sheriff, i los extranjeros residente entonces en Chile, obtuvo en el año 1819 un decreto del Gobierno del Gral Freire concediéndoles permiso para comprar terreno con el objeto de formar un cementerio para sepultar a los que de entre ellos muriesen.

Pero estaba reservado a la actual administración presentarse con resolución, i a la faz de las preocupaciones existentes, decretando la formación de un cementerio a sus propias expensas, bajo su dirección, i que constituye, en una palabra, uno de sus establecimientos nacionales, para el entierro de las personas que fallezcan en Santiago profesando una relijion distinta de la católica romana. Semejante medida hace honor al Gobierno de Chile, prueba los principios liberales que caracterizan su política, i puede mirarse como el presajio de un orden de cosas mas tolerante por lo que respecta a las materias religiosas en general. Por tanto suplicamos a Ud. mui respetuosamente se sirva transmitir al Gobierno de Chile, por conducto de la Legación de S.M, la expresión de nuestras cordiales gracias por el modo como ha procedido en este asunto.

Tenemos el honor,
R. E. Price
G. Smith
George Bringley
J. W. Brooke
Walter Grundy
Edmund Eastman
W. H. Thorsen
Joseph Brown

\author{
S. Goddes \\ Thomas Armstrong \\ W. Barrington \\ W. Purdie \\ J. Mc Dermott \\ C. B. Black \\ J. W. Wilson \\ David Doig
}


Thomas Packenham

Thomas Cliffton

Gobierno y los Agentes de S. M. Británica en Chile al Ministerio de RR.EE. de Chile, 1853).

Si bien los firmantes se equivocaban con el autor del decreto de 1819, los avances de las negociaciones se reflejaron en el Tratado a suscribir.

Precisamente, en el Tratado de Amistad, Comercio y Navegación entre la República de Chile y su Majestad la Reina del Reino Unido de la Gran Bretaña e Irlanda, firmado el 4 de octubre de 1854, canjeado el 29 de noviembre de 1855 y promulgado el 30 de noviembre de 1855, se consignaba en el artículo 15, lo siguiente:

"Libertad de conciencia. Los ciudadanos o súbditos de cada una de las Partes Contratantes, residentes en los territorios de la otra, no serán molestados, perseguidos o inquietados por causa de su creencia religiosa, sino que gozarán en ellos perfecta y entera libertad de conciencia; ni por este motivo dejarán de gozar en sus personas o propiedades la misma protección que se dispensa a los ciudadanos o súbditos naturales.

Cementerio. Si en la ciudad, villa o distrito en que residan los ciudadanos o súbditos de cada una de las Partes Contratantes no hubiere cementerio establecido para el entierro de los de su creencia religiosa, podrán, con el consentimiento de las autoridades locales superiores, y en el lugar elegido con aprobación de dichas autoridades, establecer un cementerio. Este cementerio y los entierros que se hagan en él, se sujetarán a las reglas de policía que las autoridades civiles de uno u otro país dictaren respectivamente" (Bascuñán Montes, pp. 204-205).

El Tratado constituía un avance respecto a lo establecido con otras naciones y con lo visto en el ordenamiento interno de la república. Un presagio de la tormenta que se iba a cernir sobre el gobierno de Montt en la segunda mitad del decenio, en las relaciones Iglesia y Estado, con la "cuestión del sacristán", con la disolución del bloque político pelucón, con la clausura del régimen portaliano u autoritario o del denominado Estado Constitucional Nacional Católico.

\section{Conclusiones}

La Iglesia siempre asumió la cuestión de la libertad de conciencia de una manera holística. Esto en el campo de su acción como institución, no en el ámbito individual del ejercicio académico de la teología. 
Esta imbricación entre la libertad de conciencia, la libertad de imprenta y la tolerancia de culto, siempre fue para la Iglesia, un todo. Y esto se proyectó en las denominadas querellas teológicas en el gobierno de Santa María e incluso en el debate de la separación entre la Iglesia y el Estado 22

Paradojalmente, el liberalismo político visualizó el mismo esquema, totalizador, en su visión doctrinaria sobre la influencia de la Iglesia. Al igual que la Iglesia, que debió aceptar el patronato a regañadientes, para obtener la exclusividad del culto y ser protegida por el Estado, sacrificando su libertad institucional y mediando sus nexos con Roma; el liberalismo, debió plantear gradualmente el proceso de secularización con vista a la laicización de la sociedad. En ello apuntó a sumar fuerzascomo los protestantes y la masonería- para ir socavando la hegemonía eclesial, en pro de una libertad de conciencia, cementerios de disidentes, la libertad de imprenta, etc., hasta lograr la separación de la Iglesia y el Estado (Donoso Novoa, 1946, pp. 179$326^{23}$. A esta estatolatría , con que designó el obispo Salas y Toro $(1869$, p. 8), a la veneración por el Estado; a la perspectiva liberal, que apuntaba a una mayor potestad de esta institución en desmedro de la Iglesia, estaba el otro extremo, de tinte conservador, donde las prerrogativas heredadas por el estado republicano, vía patronato, prevalecía por sobre la Iglesia. En estas corrientes la Iglesia tuvo que moverse. Ante la embestida de un bien común que mirado por los liberales, apuntaba a una irracionalidad no acoger lo "civilizado" que era la tolerancia de las opiniones y creencias y su manifestación pública, y, por parte de la élite gubernamental, se encontraba, por afección o convicción recóndita de la postura regalista, el abrir el abanico de las libertades en el campo religioso, dado que las relaciones diplomáticas más importantes era con naciones referentes de la cultura y las ideas del mundo occidental, todas con un componente protestante relevante y con una tolerancia religiosa a imitar.

Dentro de este derrotero de apertura hacia la disidencia protestante, se consideró los intereses nacionales de mantener buenas relaciones con Gran Bretaña, Francia, Estados Unidos de Norteamérica, fomentar la inmigración para los proyectos de colonización del extremo $\operatorname{sur}^{24}$ y la racionalidad en pro de la tolerancia a los disidentes, como se estaba manifestando en Gran Bretaña ${ }^{25}$.

\footnotetext{
${ }^{22}$ Hace treinta y cinco años planteamos este punto de visualizar el tema principal conjuntamente con otros, desde una perspectiva englobante, verbi gratia la mencionada separación, en conexión con otros asuntos importantes para la Iglesia. González Pizarro (1983).

${ }^{23}$ Simboliza esta interpretación. El capítulo VII, es muy representativo: "La lucha contra la influencia de la Iglesia", donde trata la tolerancia religiosa, la cuestión de los cementerios, el ocaso de la influencia de la Iglesia.

${ }^{24} \mathrm{El}$ temor católico frente a lo sucedido con la inmigración alemana en Valdivia y en el extremo sur, fue descartado absolutamente. Es más, en la transición del régimen portaliano al régimen liberal, que encabezó la administración de José Joaquín Pérez, se ultima el Tratado de Amistad, Comercio y Navegación entre Chile y Prusia, firmado el 1 de febrero de 1862, canjeado el 31 de julio de 1863 y promulgado el 24 de septiembre de 1863, en su art.16, se amplía la garantía de la libertad de conciencia, "ni por este motivo dejarán de gozar en sus personas o propiedades la misma protección que se dispensa a los
} 
Durante la primera mitad del siglo XIX lo que se entendió como libertad de conciencia fue comprendido de modo diverso, pues no se podía olvidar desde cuál perspectiva se visualizaba, de cuál tradición se planteaba o si se quiere, cuál era la arqueología del concepto que se estaba empleando. A esta dificultad, se sumaba el telón de fondo, las relaciones entre la Iglesia y el Estado, con sus respectivas prerrogativas, que, nuevamente, apuntaban a las potestades que se le asignaban- no necesariamente las establecidas por el patronato- sino lo que era, por un lado, la tradición eclesial antigua y, por otro, la soberanía que se le había dotado al Estado en la generación del acervo republicano y democrático.

Es en este contexto donde se debe examinar la discusión de la tolerancia religiosa en la época indicada, que estuvo directamente relacionada con la inmigración europea, las ideas epocales a caballo entre los siglos XVIII-XIX, la visión de la elite política gobernante y la imagen que se deseaba proyectar para el país de cara a ser visto entre las naciones progresistas de América.

\section{Referencias Bibliográficas}

Anónimo. (1828). Breve esposición de la Constitución Chilena o diálogo entre un ciudadano y un diputado al Congreso de 1828. Santiago: Imprenta de R. Rengifo. Recuperado de https://bit.ly/3320hla

Araneda Bravo, F. (1986). Historia de Ia Iglesia en Chile. Santiago: Paulinas.

Armas Asin, F. (2000). Radicalismo liberal, modernización y tolerancia religiosa en el siglo XIX. En 19th.International Congress of Historical Sciences (16p.). Oslo: University of Oslo. Recuperado de https://bit.ly/2N8nH93

Baeza Ruz, A. (2016).Circulación de biblias protestantes y tolerancia religiosa en la América del Sur post-independiente: la visión de Luke Matthews, 1826-1829 Economía y política, 3(2), 5-35. Recuperado de: https://bit.ly/329fOV6

ciudadanos o súbditos naturales", y respecto a los cementerios, no solo podían servirse de los ya establecidos, sino "la de establecer, mantener y ocupar sus propios cementerios". Bascuñán Montes (1894, p. 319).

${ }^{25}$ En Inglaterra, desde 1829, cuando se concedió a los católicos los plenos derechos civiles, a consecuencia de la reacción católica en Irlanda (Catholic Emacipation Act), trizó el principio de una Iglesia establecida, oficial y estatal, defendida por los anglicanos: esto fue asumido "marcó el triunfo del liberalismo y los comienzos de una sociedad más pluralista, para otros marcó una violación de formas constitucionales"; a lo que sumó, la formación del Movimiento de Oxford (Oxford Movement, or Tractarianism), que entre 1845 y 1851, sus líderes, pastores anglicanos se convirtieron al catolicismo, como John Newman y Henry Edward Manning, influyendo en los círculos sociales e intelectuales más prominentes de Inglaterra. Todo esto hizo, que en 1850 el Papa Pío IX, reinstaló la organización de la Iglesia Católica en Inglaterra (Landow, 2010). También, MacCulloch (2011). 
Barros Arana, D. (1892). Historia jeneral de Chile (Vol.12). Santiago: Rafael Jover Editor. Recuperado de https://bit.ly/2N8B6hn

Bascuñán Montes, A. (1894). Recopilación de tratados y convenciones celebrados entre la República de Chile y las potencias extranjeras (Vol.1). Santiago: Imprenta Cervantes. Recuperado de https://bit.ly/338x6mL

Bastian, J. (1990). Historia del protestantismo en américa latina. México: CUPSA.

Bastian, J. (1995). Protestantes, Liberales y Francmasones: sociedades de ideas y modernidad en América Latina, siglo XIX. México: FCE.

Bello López, A. (1832). Principios de derecho de jentes. Santiago: Imprenta de La Opinión. https://doi.org/10.34720/vrem-fv91.

Blancarte Pimentel, R. (2001). Breves puntualizaciones acerca de los conceptos de tolerancia y libertad religiosa. En la Comisión Nacional de los Derechos Humanos (Ed.), Memoria del seminario internacional sobre tolerancia. (págs. 101-107). México, DF: CNDH. Recuperado de https://bit.ly/328pDmm

Brahm García, E. (1992). La crisis del conservantismo chileno en la segunda mitad del siglo XX. Política, gobierno y régimen de gobierno en el itinerario intelectual de don Ramón Sotomayor Valdés. Revista chilena de derecho, 19(1), 7-33. Recuperado de https://bit.ly/2NytRhN

Brahm García, E. (2007). Mariano Egaña. Derecho y política en la fundación de la república conservadora. Santiago: Centro de Estudios Bicentenario.

Bravo Lira, B. (1992). El absolutismo ilustrado en Hispanoamérica: Chile (1760-1860) de Carlos III a Portales y Montt. Santiago: Universitaria.

Carpio Sardón, L. (2007). La libertad religiosa en el Perú. Derecho eclesiástico del estado. Piura: Universidad de Piura.

Castillo Didier, M. (2014). Francisco de Miranda y Chile. Tiempo y espacio, 24(62), 1536. Recuperado de https://bit.ly/34rmGyD

Catanzaro Román, M. (2015). Relaciones entre iglesia y estado argentino: un análisis desde la perspectiva de los derechos humanos (Tesis Doctoral). Universidad Carlos III de Madrid. Departamento de derecho internacional público, eclesiástico y filosofía del derecho. Recuperado de https://bit.ly/36xYaxN

Cavieres Figueroa, E. (1988). Comercio chileno y comerciantes ingleses, 1820-1880: un ciclo de historia económica. Valparaíso: Universidad Católica de Valparaíso.

Collier, S. (2005). Ideas y políticas de la independencia chilena, 1808-1833. Santiago: Ediciones Universidad Católica de Chile. 
Concha Contreras, M. (2013). La Iglesia y los protestantismos en Chile decimonónico: una aproximación histórica (1845-1865). En B. Silva Torrealba (Comp.). Historia del cristianismo en Chile y América (Vol. 1, pp. 99-118), Viña del Mar: Universidad Católica del Maule.

Chile. (1900). Boletín de las leyes i decretos del gobierno, 1819-1820. Santiago: Imprenta nacional.

Chocano Mena, M. (2010). Lima masónica: las logias simbólicas y su progreso en el medio urbano a fines del siglo XIX. Revista de Indias, 70(249), 409-444. https://doi.org/10.3989/revindias.2010.013.

Díaz-Trechuelo, L. (1999). Bolívar, Miranda, O'Higgins, San Martín. Cuatro vidas cruzadas. Madrid: Encuentro.

Donoso Novoa, R. (1946). Las ideas políticas en Chile. México: Fondo de Cultura Económica.

Enríquez Agraznar, L. (2013). Un proyecto de iglesia nacional. En F. Silva Vargas y J. Vargas Cariola (Eds.). Historia de la República de Chile.1808-1826. El fin de la monarquía y los orígenes de la república (pp. 709-776). Santiago: Zig-Zag.

Errázuriz Zañartu, F. (1861). Chile bajo el imperio de la Constitución de 1828. Santiago: Imprenta Chilena. Recuperado de https://bit.ly/329zzfo

Estellé Méndez, P. (1967) El debate de 1865 sobre la libertad de culto y de conciencia. Estudios de Historia de las Instituciones Políticas y Sociales, (2), 181-225.

Fernández Sebastián, J. (2011). Toleration and freedom of expression in the hispanic world between enlightenment and liberalism. Past and present, 211(1), 159-197. https://doi.org/10.1093/pastj/gtq065.

Feroni, Julián J. (2015). Reforma eclesiástica y tolerancia de cultos en Cuyo. Debates a través de la prensa. Folia histórica del nordeste, (23), 151-172. http://dx.doi.org/10.30972/fhn.02339.

González Manso, A. (2014). Tolerancia religiosa y modelo de iglesia en España en la primera mitad del siglo XIX. Historia Constitucional, (15), 113-153. https://dx.doi.org/10.17811/hc.v0i15.400.

González Pizarro, J. (1983). En torno a la separación de la Iglesia y el Estado: un esquema. Anuario de la historia de la Iglesia en Chile, 1(1), 63-94.

González Pizarro, J. (1989). Situación inmigratoria, interpretación jurídica y proyección política en el contexto de la presencia de los jesuitas en Uruguay, 1858-1859. Examen de los factores de su extrañamiento. Pesquisas. Historia, (27), 49-72. 
González Pizarro, J. (1990). Claudio Gay y la historiografía chilena. El contexto histórico-cultural en la formulación de una concepción historiográfica. Caravelle, Cahiers du monde hispanique et luso-brésilien, (55), 83-104. Recuperado de https://bit.ly/2oAYnz4

González Pizarro, J. (1999). La política de España en América bajo Isabel II. Navarra: Newbook.

González Pizarro, J. (2006). La revista católica en el decenio de 1850; barómetro de los cambios en la sociedad chilena. Tercer Milenio (Antofagasta), 11(11), 26-32.

González Pizarro, J. (2006b). El Código Civil de Andrés Bello: su lectura por la Iglesia Católica, Revista de derecho (Coquimbo. En línea), 13(1), 17-49. https://doi.org/10.22199/S07189753.2006.0001.00002.

Gregorio XVI. Vaticano II. Mirari Vos sobre los errores modernos. Agosto 15 de 1832. Recuperado de https://bit.ly/2NblvNc

Koselleck, R. (1993). Futuro pasado. Para una semántica de los tiempos históricos. Barcelona: Paidós.

Krebs Wilckens, R. (2002). La Iglesia de América Latina en el siglo XIX. Santiago: Ediciones Universidad Católica de Chile.

Landow, G. (4 de julio de 2010). El catolicismo romano en la Gran Bretaña decimonónica. Recuperado el 12 de diciembre de 2017, de https://bit.ly/2PDkEr4

Lastarria Santander, J. (1856). La Constitución Política de la República de Chile. Valparaíso: Imprenta del Comercio. Recuperado de https://bit.ly/2N9YrPR

Letelier Madariaga, V. (1901). La Gran Convención de 1831-1833. Recopilación de las actas, sesiones, discursos, proyectos i artículos de diarios relativos a la Constitución de 1833. Santiago: Imprenta Cervantes. Recuperado de https://bit.ly/2C8PDUe

Llamazares Fernández, D. (2002).Derecho de la libertad de conciencia (Vol.1). Madrid: Civitas.

MacCulloch, D. (2011). Historia de la cristiandad. (R. García Pérez, trad.). Barcelona: Random House Mondadori.

Martina, G. (1974). La Iglesia de Lutero a nuestros días (Vol. 3). Madrid: Cristiandad.

Marsh, J. (2011). El cementerio de Disidente y la participación británica en Valparaíso $=$ The Cementerio de Disidentes and the british involvement in Valparaiso. En M. Prain (Ed.). Legado británico en Valparaíso = British legacy in Valparaiso (pp. 240-241). Santiago: RIL. 
Ministerio de RR.EE. de Chile. Copiador de correspondencia enviada a los Agentes Diplomáticos y Consulares extranjeros. (1850). [Manuscrito impreso] Chile, Ministerio de Relaciones Exteriores. Archivo general histórico, Fondo Histórico. Santiago. Recuperado de https://bit.ly/2PzoHVo

Notas enviadas por el Gobierno y los Agentes de S. M. Británica en Chile al Ministerio de RR.EE. de Chile. (1853). [Manuscrito impreso] Chile, Ministerio de Relaciones Exteriores. Archivo general histórico, Fondo Histórico. Santiago. Recuperado de https://bit.ly/2PzoHVo

Ortíz Mesa, L. (2013). La Iglesia católica y la formación del Estado-nación en América Latina en el siglo XIX.El caso colombiano. Almanack, (6), 525. https://doi.org/10.1590/2236-463320130601.

Pacheco Carreño, W. (2008).Primera sociedad bíblica en Valparaíso: presencia, propósitos y obra en la segunda mitad del siglo XIX. En M. Concha Contreras, W. Pacheco Carreño y F. Vergara Benítez (Eds.). Actas del segundo simposio de historia religiosa de Valparaíso (pp. 69-99). Valparaíso: Ediciones Universitarias de Valparaíso.

Pacheco Carreño, W. (2011). Union Church: hechos legado por una comunidad evangélica reformada en Valparaíso del siglo XIX (1847-1883). En M. Concha Contreras (Ed.). Actas del tercer simposio de historia religiosa de Valparaíso (pp. 53-81). Valparaíso: Ediciones Universitarias de Valparaíso.

Pío IX. Vaticano II. Encíclica Quanta Cura y el Syllabus. 8 de diciembre de 1864. Recuperado de https://bit.ly/2NIClxI

Romero, J. (1985) El pensamiento político de la emancipación 1790-1825 (Vol. 1). Caracas: Biblioteca Ayacucho.

Salas y Toro, J. (1869) El juramento civil de los obispos ante la relijion i el derecho i apuntes jurídicos-históricos sobre el juramento civil de los obispos en España i Chile por un ciudadano católico. Santiago: Imprenta del Correo. Recuperado de https://bit.ly/2Cd7/8Q

Salas y Toro, J. (1872) Los cementerios (2a ed.). Valparaíso: Imprenta del Mercurio. Recuperado de https://bit.ly/2PR42My

Salinas Campos, M. (1976) La reflexión teológica en torno a la revolución y al papel de la Iglesia en la naciente república. Anales de la Facultad de Teología, 27(2), 13-71.

Schurmann Pacheco, M. y Cooligham Sanguinetti, M. (1996). Historia del Uruguay (Vol. 2). Montevideo: Talleres Gráficos Monteverde. 
Serrano Pérez, S. (2005) La privatización del culto y la piedad católicas. En R. Sagredo Baeza y C. Gazmuri, Cristián, Historia de la vida privada en Chile (Vol. 2, pp. 139-155). Santiago: Aguilar.

Serrano Pérez, S. (2008). ¿Qué hacer con Dios en la República?. Política y secularización en Chile (1845-1885). Santiago: Fondo de Cultura Económica, pp.183-185.

Starck, C. (1996). Raíces modernas de la libertad religiosa moderna. Revista española de derecho constitucional, 16 (47), 9-27. Recuperado de https://bit.ly/2NgK0cE

Stuven Vattier, A. (2016). Tolerancia religiosa y orden social: Juan Egaña vs. José María Blanco White. Ariadna histórica, (5), 23-44. Recuperado de https://bit.ly/2NDbJn9

Subercaseaux Sommerhoff, B. (2011) Historia de las ideas y de la cultura en Chile (Vol. 1). Santiago: Universitaria.

Theophilos. (1863). Seis cartas al señor D. Antonio Varas, Presidente de la Cámara de Diputado sobre las relaciones entre la Iglesia y el Estado en Chile. Valparaíso: Imprenta del Universo de G. Helfmann. Recuperado de https://bit.ly/2WGno8z

Valencia Avaria, L. (1986). Anales de la República (Vol. 1 y 2). Santiago: Andrés Bello.

Vera Urbano, F. (2003). La libertad religiosa en el pensamiento católico según los tratados de teología moral y la literatura polémica del siglo XVIII. Revista de estudios histórico-jurídicos, (25), 445-474. https://doi.org/10.4067/s0716-54552003002500012.

Zea Aguilar, L. (1943) El Positivismo en México. México, DF: El Colegio de México.

\section{Para citar este artículo bajo Norma APA 6a ed.}

González Pizarro, J. (2019). El concepto de la tolerancia religiosa en Chile en la primera mitad del siglo XIX. Revista de Derecho (Coquimbo. En línea), 26, e3598. https://doi.org/10.22199/issn.07189753-2019-0009

\section{DOI}

Copyright del articulo: @2019 José González.

\section{(c) BY}

Este es un artículo de acceso abierto, bajo licencia Creative Commons BY 4.0. 